\title{
Competitiveness Evaluation of High-tech Zone based on Industrial Cluster
}

\author{
Bingke Zhu, a , Xiaomiao Gui ${ }^{2, b}$, *, and Chaofeng Zhou ${ }^{3, c}$ \\ ${ }^{1}$ Informatics Department, Hubei University of Medicine, South Renmin Road, Shiyan, China \\ ${ }^{2}$ Informatics Department, Hubei University of Medicine, South Renmin Road, Shiyan, China \\ ${ }^{3}$ Informatics Department, Hubei University of Medicine, South Renmin Road, Shiyan, China \\ aecho1933@qq.com, bxxm@imgxm.com, 1903352055@qq.com \\ *Corresponding author
}

Keywords: Industrial Cluster, Competitiveness, High-tech Zone.

\begin{abstract}
In order to improve the competitiveness of High-tech Zones from the angle of industrial cluster, this paper constructed the competitiveness evaluation index system of high-tech Zone based on industrial cluster. Using AHP to determine the index weight, this paper analyzed the influential factors affecting the High-tech Zone's competitiveness. Using synthetic fuzzy assessment to calculate the overall level of High-tech Zone, this paper took Xi' an high-tech Zone as an example to carry out empirical analysis. It is concluded that the competitiveness of Xi'an high-tech Zone is in general level, which provides a reference for improving the competitiveness of Xi'an High-tech Zone and other High-tech Zones in China.
\end{abstract}

\section{Introduction}

With the development of global science and technology, a large number of High-tech enterprises have also been born. These High-tech enterprises gathered together because of their own demand for innovative elements, resulting in a huge economic and social benefit, thus forming a high-tech industrial cluster. Silicon Valley is a model of success in the United States. It has become the focus of world economic activity, and it has become the gathering place of technology and knowledge innovation. Although the development of High-tech Zones in China has made achievements, there are still many problems in the process of development, such as low agglomeration and weak concentration of high and new technology as well as relatively low technical innovation ability, which causes the low competitiveness of High-tech Zone. Therefore, it is of great significance to study the competitiveness of High-tech Zone based on industrial cluster.

\section{The Concept of High-tech Zone Competitiveness based on Industrial Cluster}

This paper combined the industrial cluster, high-tech Zone competitiveness theory and regional competitiveness to summarize the concept of High-tech Zone competitiveness based on industrial clusters. The competitiveness of High-tech Zones based on industrial clusters is a comprehensive collection concept consisting of entrepreneurial environmental competitiveness, innovation competitiveness, sustainable development competitiveness and industrial cluster competitiveness. The definition is as follows: The High-tech Zone that forms the industrial cluster is based on various asset elements such as infrastructure, enterprise, technical conditions, capital, etc., and is operated in the dynamic network relationship of the relevant organizations in the High-tech Zone, which has the right to utilization of the environment and has the advantage of continuous competition to improve the overall strength of the High-tech Zone.

\section{Selection of Evaluation Indicators}

Based on the principles of scientific, comprehensiveness and comparability selecting indicators and research methods, this paper combined with the actual situation of High-tech Zone, which 
determined 31 initial evaluation indicators. The first level of the evaluation indicator system is that the target layer makes the final evaluation result from the competitiveness of the overall high-tech Zone. The second level is that the criteria layer includes basic support and industrial cluster support. The third level is that the sub-criteria layer includes 31 indicators, which are obtained by refining the two criterion layers. This paper uesd the Delphi method (Expert Consultation Method) determined the final evaluation index system through questionnaire survey. The survey consisted 28 participants, including experts in High-tech Zones and High-tech Zone management committee staffs. Combined with the degree of expert accreditation $<=60 \%$ as the elimination of the standard, 28 indicators were left. Based on the hierarchy of indicators, a framework for evaluating the competitiveness of high-tech Zones was established, as shown in table 1.

Table 1 Evaluation Model Framework.

\begin{tabular}{|c|c|c|c|}
\hline Target layer & $\begin{array}{l}\text { First-rank } \\
\text { Evaluation } \\
\text { Indexes }\end{array}$ & $\begin{array}{l}\text { Second-rank } \\
\text { Evaluation } \\
\text { Indexes }\end{array}$ & Third-rank Evaluation Indexes \\
\hline \multirow{28}{*}{$\begin{array}{l}\text { Competitiveness } \\
\text { Evaluation of } \\
\text { High-tech Zone } \\
\text { based on } \\
\text { Industrial Cluster } \\
\text { (O) }\end{array}$} & \multirow{8}{*}{$\begin{array}{l}\text { Foundation } \\
\text { Support } \\
\text { Force(A) }\end{array}$} & \multirow{3}{*}{$\begin{array}{l}\text { Infrastructure } \\
\text { Facilities }\left(\mathrm{A}_{1}\right)\end{array}$} & $\begin{array}{l}\text { Degree of Infrastructure Construction such as Transportation, } \\
\text { Water and Electricity }\left(\mathrm{A}_{11}\right)\end{array}$ \\
\hline & & & Service Level of Intermediary Agencies $\left(\mathrm{A}_{12}\right)$ \\
\hline & & & Network Communication’s Situation( $\left(\mathrm{A}_{13}\right)$ \\
\hline & & \multirow{5}{*}{$\begin{array}{l}\text { Government } \\
\operatorname{role}\left(\mathrm{A}_{2}\right)\end{array}$} & Productivity Promotion Centre’s Inputs $\left(\mathrm{A}_{21}\right)$ \\
\hline & & & Productivity Promotion Centre’s Assets $\left(\mathrm{A}_{22}\right)$ \\
\hline & & & The efficiency of Government Affairs $\left(\mathrm{A}_{23}\right)$ \\
\hline & & & Degree of Protection Intellectual Property Rights $\left(\mathrm{A}_{24}\right)$ \\
\hline & & & Degree of Implementation of Preferential Policies $\left(\mathrm{A}_{25}\right)$ \\
\hline & \multirow{20}{*}{$\begin{array}{c}\text { Industrial } \\
\text { cluster's } \\
\text { competitiveness } \\
\text { (B) }\end{array}$} & \multirow{3}{*}{$\begin{array}{c}\text { Cluster } \\
\text { Concentration } \\
\text { Degree }\left(B_{1}\right)\end{array}$} & $\begin{array}{l}\text { Number of Enterprises in High-tech Zones / Area of High-tech } \\
\text { Zones }\left(B_{11}\right)\end{array}$ \\
\hline & & & Number of Incubating Enterprises / Area of Hatchery $\left(\mathrm{B}_{12}\right)$ \\
\hline & & & Number of University Science and Technology Parks $\left(\mathrm{B}_{13}\right)$ \\
\hline & & \multirow{6}{*}{$\begin{array}{c}\text { Cluster } \\
\text { Aggregation } \\
\text { Degree }\left(\mathrm{B}_{2}\right)\end{array}$} & Degree of Cooperation-competition between Enterprises $\left(\mathrm{B}_{21}\right)$ \\
\hline & & & $\begin{array}{l}\text { Degree of Contact between Enterprises and Intermediary } \\
\text { Services }\left(\mathrm{B}_{22}\right)\end{array}$ \\
\hline & & & $\begin{array}{c}\text { Degree of Cooperation between Enterprises and Research } \\
\text { Institutes in the Cluster( }\left(B_{23}\right)\end{array}$ \\
\hline & & & Industry Chain Integrity $\left(\mathrm{B}_{24}\right)$ \\
\hline & & & $\begin{array}{l}\text { The Number of Enterprises Provided Services by Productivity } \\
\text { Promotion }\left(\mathrm{B}_{25}\right)\end{array}$ \\
\hline & & & Number of Trainees $\left(\mathrm{B}_{26}\right)$ \\
\hline & & \multirow{6}{*}{$\begin{array}{l}\text { Technical } \\
\text { Innovation } \\
\text { Force }\left(B_{3}\right)\end{array}$} & R\&D Expenditure / Total Income $\left(\mathrm{B}_{31}\right)$ \\
\hline & & & $\begin{array}{l}\text { Number of High-tech Enterprises / Total Number of Enterprises } \\
\text { in High-tech Zones }\left(B_{32}\right)\end{array}$ \\
\hline & & & $\begin{array}{c}\text { Total Number of Scientific and Technical } \\
\text { Personnel/Employees }\left(\mathrm{B}_{33}\right) \\
\end{array}$ \\
\hline & & & Technical Income / Total Income $\left(\mathrm{B}_{34}\right)$ \\
\hline & & & High-tech Enterprise Industrial Added Value $\left(\mathrm{B}_{35}\right)$ \\
\hline & & & Number of Patent Grants (items)(B $\left.{ }_{36}\right)$ \\
\hline & & \multirow{5}{*}{$\begin{array}{c}\text { Sustainable } \\
\text { Development } \\
\text { Force }\left(\mathrm{B}_{4}\right)\end{array}$} & $\begin{array}{l}\text { Number of Junior College or Above / Number of Employees at } \\
\left.\text { the end of the year( } B_{41}\right)\end{array}$ \\
\hline & & & High-tech Zone Enterprise Industrial Added Value $\left(\mathrm{B}_{42}\right)$ \\
\hline & & & Tax Paid $\left(\mathrm{B}_{43}\right)$ \\
\hline & & & Foreign Exchange Earned by Exports $\left(\mathrm{B}_{44}\right)$ \\
\hline & & & Comfort Level of the Human Habitat Environment $\left(\mathrm{B}_{45}\right)$ \\
\hline
\end{tabular}

\section{Empirical Analysis}

Xi'an High-tech Zone was approved by the State Council as the national High-tech Zone in March 1991. At present, it has more than 18,000 domestic and foreign enterprises. Xi'an High-tech Zone has formed eight industrial clusters led by electronic information, biomedicine, advanced manufacturing, and modern service industries, including communications, photovoltaics and LEDs, 
electronic components, power equipment and energy technologies, automobiles, biopharmaceuticals, software and services, outsourcing, innovative service industries, etc. Xi'an High-tech Zone has become a successful case for the development of High-Tech industries in inland cities. Its important indicators such as operating income have ranked third in the national high-tech Zone. After more than 20 years of hard work, Xi'an High-tech Zone has become a national advanced High-tech Zone, and it has established the development direction of building a world-class High-tech Zone. However, there is still a big gap between the development of world-renowned High-tech Zones.

\subsection{AHP determines Indicator Weights}

This paper used qualitative and quantitative analytic hierarchy process to calculate and analyze the weight of evaluation indicators at all levels. Taking Xi'an High-tech Zone as the evaluation object, we chose the staff of Xi'an High-tech Zone Management Committee, the staff of the high-tech Zone and related experts in this field as the survey objects to fill out the questionnaire. According to the analysis of the influence of Xi'an High-tech Zone, 23 questionnaires were distributed and 21 were returned, with an effective rate of $91.3 \%$. Since some of the average scores scored by 21 experts are not integers, so we facilitated the analysis of their approximations. The resulting judgment matrix is shown in Table 2.

Table 2 Final Weight Calculation Result.

\begin{tabular}{|c|c|c|c|c|c|c|c|}
\hline Target layer & \begin{tabular}{|c|} 
First-rank \\
Evaluation \\
Indexes
\end{tabular} & Weight & $\begin{array}{c}\text { Second-rank } \\
\text { Evaluation Indexes }\end{array}$ & Weight & $\begin{array}{c}\text { Third-rank } \\
\text { Evaluation Indexes }\end{array}$ & Weight & $\begin{array}{c}\text { Comprehensive } \\
\text { Weights }\end{array}$ \\
\hline \multirow{28}{*}{$\begin{array}{l}\text { Competitiveness } \\
\text { Evaluation of } \\
\text { High-tech Zone } \\
\text { based on } \\
\text { Industrial Cluster }\end{array}$} & \multirow{8}{*}{ A } & \multirow{8}{*}{0.25} & \multirow{3}{*}{$\mathrm{A}_{1}$} & \multirow{3}{*}{0.25} & $\mathrm{~A}_{11}$ & 0.23 & 0.0149 \\
\hline & & & & & $\mathrm{A}_{12}$ & 0.14 & 0.0085 \\
\hline & & & & & $\mathrm{A}_{13}$ & 0.63 & 0.0391 \\
\hline & & & \multirow{5}{*}{$A_{2}$} & \multirow{5}{*}{0.75} & $\mathrm{~A}_{21}$ & 0.15 & 0.0281 \\
\hline & & & & & $A_{22}$ & 0.05 & 0.0088 \\
\hline & & & & & $\mathrm{A}_{23}$ & 0.11 & 0.0204 \\
\hline & & & & & $\mathrm{A}_{24}$ & 0.38 & 0.0718 \\
\hline & & & & & $\mathrm{A}_{25}$ & 0.31 & 0.0584 \\
\hline & \multirow{20}{*}{ B } & \multirow{20}{*}{0.75} & \multirow{3}{*}{$\mathrm{B}_{1}$} & \multirow{3}{*}{0.11} & $\mathrm{~B}_{11}$ & 0.30 & 0.0239 \\
\hline & & & & & $\mathrm{B}_{12}$ & 0.54 & 0.0434 \\
\hline & & & & & $\mathrm{B}_{13}$ & 0.16 & 0.0131 \\
\hline & & & \multirow{6}{*}{$\mathrm{B}_{2}$} & \multirow{6}{*}{0.26} & $\mathrm{~B}_{21}$ & 0.25 & 0.0472 \\
\hline & & & & & $\mathrm{B}_{22}$ & 0.08 & 0.0158 \\
\hline & & & & & $\mathrm{B}_{23}$ & 0.18 & 0.0340 \\
\hline & & & & & $\mathrm{B}_{24}$ & 0.40 & 0.0760 \\
\hline & & & & & $\mathrm{B}_{25}$ & 0.03 & 0.0070 \\
\hline & & & & & $\mathrm{B}_{26}$ & 0.06 & 0.0113 \\
\hline & & & \multirow{6}{*}{$\mathrm{B}_{3}$} & \multirow{6}{*}{0.47} & $\mathrm{~B}_{31}$ & 0.23 & 0.0841 \\
\hline & & & & & $\mathrm{B}_{32}$ & 0.08 & 0.0292 \\
\hline & & & & & $\mathrm{B}_{33}$ & 0.18 & 0.0624 \\
\hline & & & & & $\mathrm{B}_{34}$ & 0.18 & 0.0624 \\
\hline & & & & & $\mathrm{B}_{35}$ & 0.11 & 0.0393 \\
\hline & & & & & $\mathrm{B}_{36}$ & 0.22 & 0.0786 \\
\hline & & & \multirow{5}{*}{$\mathrm{B}_{4}$} & \multirow{5}{*}{0.16} & $\mathrm{~B}_{41}$ & 0.15 & 0.0187 \\
\hline & & & & & $\mathrm{B}_{42}$ & 0.25 & 0.0300 \\
\hline & & & & & $\mathrm{B}_{43}$ & 0.09 & 0.0111 \\
\hline & & & & & $\mathrm{B}_{44}$ & 0.26 & 0.0325 \\
\hline & & & & & $\mathrm{B}_{45}$ & 0.25 & 0.0300 \\
\hline
\end{tabular}

From the results of the above AHP analysis, we can know that each criterion layer has C.R.<0.1. Therefore, the judgments of each criterion layer are consistent, and the total weights are added to 1 . The comprehensive calculation results are as follows: 


$$
\begin{aligned}
& W_{O}=[0.25,0.75] \\
& W_{A}=[0.25,0.75] \\
& W_{B}=[0.11,0.26,0.47,0.16] \\
& W_{A 1}=[0.23,0.14,0.63] \\
& W_{A 2}=[0.15,0.05,0.11,0.38,0.31] \\
& W_{B 1}=[0.30,0.54,0.16] \\
& W_{B 2}=[0.25,0.08,0.18,0.18,0.40,0.03,0.06] \\
& W_{B 3}=[0.23,0.08,0.18,0.18,0.11,0.22] \\
& W_{B 4}=[0.15,0.25,0.09,0.26,0.25]
\end{aligned}
$$

\begin{tabular}{|c|c|c|c|c|c|c|c|c|c|c|c|}
\hline \multicolumn{6}{|c|}{ Indicator Layer } & \multicolumn{6}{|c|}{ Number of people in each file(points) } \\
\hline $\begin{array}{l}\text { Target } \\
\text { Layer }\end{array}$ & Weight & $\begin{array}{l}\text { Second-rank } \\
\text { Evaluation } \\
\text { Indexes }\end{array}$ & Weight & \begin{tabular}{|c|} 
Third-rank \\
Evaluation \\
Indexes
\end{tabular} & Weight & 9 & 7 & 5 & 3 & 1 & Score \\
\hline \multirow{8}{*}{ A } & \multirow{8}{*}{0.25} & \multirow{3}{*}{$A_{1}$} & \multirow{3}{*}{0.25} & $\mathrm{~A}_{11}$ & 0.23 & 0.3 & 0.4 & 0.2 & 0.1 & 0 & 6.8 \\
\hline & & & & $\mathrm{A}_{12}$ & 0.14 & 0.2 & 0.3 & 0.4 & 0.1 & 0 & 6.2 \\
\hline & & & & $\mathrm{A}_{13}$ & 0.63 & 0.4 & 0.3 & 0.2 & 0.1 & 0 & 7.0 \\
\hline & & \multirow{5}{*}{$\mathrm{A}_{2}$} & \multirow{5}{*}{0.75} & $A_{21}$ & 0.15 & 0.3 & 0.2 & 0.4 & 0.1 & 0 & 6.4 \\
\hline & & & & $A_{22}$ & 0.05 & 0.2 & 0.3 & 0.4 & 0.1 & 0 & 6.2 \\
\hline & & & & $\mathrm{A}_{23}$ & 0.11 & 0.1 & 0.4 & 0.4 & 0.1 & 0 & 6.0 \\
\hline & & & & $\mathrm{A}_{24}$ & 0.38 & 0.2 & 0.3 & 0.4 & 0.1 & 0 & 6.2 \\
\hline & & & & $\mathrm{A}_{25}$ & 0.31 & 0.4 & 0.3 & 0.1 & 0.2 & 0 & 6.8 \\
\hline \multirow{20}{*}{ B } & \multirow{20}{*}{0.75} & \multirow{3}{*}{$B_{1}$} & \multirow{3}{*}{0.11} & $\mathrm{~B}_{11}$ & 0.30 & 0.4 & 0.3 & 0.2 & 0.1 & 0 & 7.0 \\
\hline & & & & $B_{12}$ & 0.54 & 0.3 & 0.2 & 0.3 & 0.2 & 0 & 6.2 \\
\hline & & & & $\mathrm{B}_{13}$ & 0.16 & 0.5 & 0.2 & 0.2 & 0.1 & 0 & 7.2 \\
\hline & & \multirow{6}{*}{$B_{2}$} & \multirow{6}{*}{0.26} & $\mathrm{~B}_{21}$ & 0.25 & 0.3 & 0.2 & 0.3 & 0.2 & 0 & 6.0 \\
\hline & & & & $\mathrm{B}_{22}$ & 0.08 & 0.3 & 0.2 & 0.2 & 0.3 & 0 & 6.0 \\
\hline & & & & $\mathrm{B}_{23}$ & 0.18 & 0.4 & 0.2 & 0.2 & 0.2 & 0 & 6.6 \\
\hline & & & & $B_{24}$ & 0.40 & 0.2 & 0.3 & 0.3 & 0.2 & 0 & 6.0 \\
\hline & & & & $\mathrm{B}_{25}$ & 0.03 & 0.3 & 0.3 & 0.3 & 0.1 & 0 & 6.6 \\
\hline & & & & $\mathrm{B}_{26}$ & 0.06 & 0.2 & 0.3 & 0.3 & 0.2 & 0 & 6.0 \\
\hline & & \multirow{6}{*}{$\mathrm{B}_{3}$} & \multirow{6}{*}{0.47} & $\mathrm{~B}_{31}$ & 0.23 & 0.3 & 0.2 & 0.2 & 0.3 & 0 & 6.0 \\
\hline & & & & $\mathrm{B}_{32}$ & 0.08 & 0.4 & 0.3 & 0.2 & 0.1 & 0 & 7.0 \\
\hline & & & & $\mathrm{B}_{33}$ & 0.18 & 0.3 & 0.2 & 0.3 & 0.2 & 0 & 6.2 \\
\hline & & & & $\mathrm{B}_{34}$ & 0.18 & 0.3 & 0.3 & 0.2 & 0.2 & 0 & 6.4 \\
\hline & & & & $\mathrm{B}_{35}$ & 0.11 & 0.3 & 0.2 & 0.3 & 0.2 & 0 & 6.2 \\
\hline & & & & $\mathrm{B}_{36}$ & 0.22 & 0.3 & 0.2 & 0.2 & 0.3 & 0 & 6.0 \\
\hline & & \multirow{5}{*}{$\mathrm{B}_{4}$} & \multirow{5}{*}{0.16} & $\mathrm{~B}_{41}$ & 0.15 & 0.3 & 0.2 & 0.3 & 0.2 & 0 & 6.2 \\
\hline & & & & $\mathrm{B}_{42}$ & 0.25 & 0.3 & 0.3 & 0.2 & 0.2 & 0 & 6.4 \\
\hline & & & & $\mathrm{B}_{43}$ & 0.09 & 0.4 & 0.2 & 0.3 & 0.1 & 0 & 6.8 \\
\hline & & & & $\mathrm{B}_{44}$ & 0.26 & 0.3 & 0.3 & 0.2 & 0.2 & 0 & 6.4 \\
\hline & & & & $\mathrm{B}_{45}$ & 0.25 & 0.3 & 0.2 & 0.2 & 0.3 & 0 & 6.0 \\
\hline
\end{tabular}

\subsection{Evaluation Using Fuzzy Comprehensive Evaluation Model}

(1) Establish a collection of reviews. The competitive comment set is defined as five comments of $\mathrm{P}=$ [stronger, strong, average, weak, weaker], and their corresponding quantitative value sets are $[9,7,5,3,1]$. The staff of the Xi'an High-tech Zone Management Committee, the staff of the company in the high-tech Zone, and related experts will be combined with the indicators to judge the comments. Multiply the expert score result/total number of people by the weighting factor, and the calculation result reserve a decimal number for easy calculation, as shown in Table 3.

Table 3 Rating Table.

(2) First-level fuzzy comprehensive evaluation

As can be seen from the graph, the weighted fuzzy subset of criterion $A_{1}$ is $W_{A 1}$. 


$$
\mathrm{R}_{1}=\left[\begin{array}{lllll}
0.3 & 0.4 & 0.2 & 0.1 & 0 \\
0.2 & 0.3 & 0.4 & 0.1 & 0 \\
0.4 & 0.3 & 0.2 & 0.1 & 0
\end{array}\right]
$$

Fuzzy comprehensive judgment matrix:

$$
B_{1}{ }^{\prime}=W_{A 1} \cdot R_{1}=(0.23,0.14,0.63) \cdot\left[\begin{array}{ccccc}
0.3 & 0.4 & 0.2 & 0.1 & 0 \\
0.2 & 0.3 & 0.4 & 0.1 & 0 \\
0.4 & 0.3 & 0.2 & 0.1 & 0
\end{array}\right]=(0.349,0.323,0.228,0.10,0)
$$

Equally available:

$$
\begin{gathered}
B_{2}{ }^{\prime}=W_{A 2} \cdot R_{2}=(0.266,0.296,0.307,0.131,0) \\
B_{3}{ }^{\prime}=W_{B 1} \cdot R_{3}=(0.362,0.23,0.254,0.154,0) \\
B_{4}{ }^{\prime}=W_{B 2} \cdot R_{4}=(0.272,0.249,0.274,0.205,0) \\
B_{5}{ }^{\prime}=W_{B 3} \cdot R_{5}=(0.308,0.226,0.229,0.237,0) \\
B_{6}{ }^{\prime}=W_{B 4} \cdot R_{6}=(0.309,0.251,0.224,0.216,0)
\end{gathered}
$$

(3) Second-stage Fuzzy Comprehensive Evaluation

As the single factor of Grade Two fuzzy evaluation is the result of first-level evaluation, the matrix of the first-level fuzzy comprehensive evaluation is used as a single factor matrix of the two-level fuzzy comprehensive evaluation.

$$
\begin{aligned}
& R_{1}{ }^{\prime}=\left[\begin{array}{l}
B_{1}{ }^{\prime} \\
B_{2}{ }^{\prime}
\end{array}\right]=\left[\begin{array}{lllll}
0.349 & 0.323 & 0.228 & 0.10 & 0 \\
0.226 & 0.296 & 0.307 & 0.131 & 0
\end{array}\right] \\
& B_{1}{ }^{\prime \prime}=W_{A} \cdot R_{1}{ }^{\prime}=(0.25,0.75) \cdot\left[\begin{array}{lllll}
0.349 & 0.323 & 0.228 & 0.10 & 0 \\
0.226 & 0.296 & 0.307 & 0.131 & 0
\end{array}\right]=(0.28675,0.30275,0.28725,0.12325,0)(8) \\
& B_{2}{ }^{\prime \prime}=W_{B} \cdot R_{2}{ }^{\prime}=(0.30474,0.23642,0.24265,0.21619,0)
\end{aligned}
$$

(4) Third-stage Fuzzy Comprehensive Evaluation

Because the single factor of level three fuzzy evaluation is the result of two-level evaluation, the matrix of the two-level fuzzy comprehensive evaluation is regarded as a single factor matrix of the three-level fuzzy comprehensive evaluation.

$$
B=(0.25,0.75) \cdot\left[\begin{array}{l}
0.28675,0.30275,0.28725,0.12325,0 \\
0.30474,0.23642,0.24265,0.21619,0
\end{array}\right]=(0.30024,0.253002,0.253,0.19295,0)(10)
$$

Normalized to get a result: $B=(0.300,0.253,0.254,0.193,0)$

(5)Calculate the Comprehensive Evaluation Value: $W$

$$
W=B . F=(0.300,0.253,0.254,0.193,0) \cdot\left(9,7,5,3,11^{\top}=6.32\right.
$$

From the above calculation, since $5<\mathrm{x}=6.32<7$, according to the comment weighted coefficient matrix $F=(9,7,5,3,1)^{\mathrm{T}}$ corresponding comments $p$, we learned that Xi'an high-tech Zone competitive level between general and strong, the competitiveness of a strong bias. It shows that the industrial cluster of Xi'an High-tech Zone is not mature enough, and the development of Xi'an High-tech Zone is in the growing stage.

\section{Summary}

This paper constructs the evaluation Index system of high-tech Zone competitiveness based on industrial cluster. The paper draws the conclusion that the Xi'an high-tech area development is at a 
growth stage by using the analytic hierarchy process to carry on the index assignment value and by making an empirical analysis of Xi'an high tech Zone. The conclusion is made to improve the competitiveness of Xi'an High-tech Zone and provide decision-making reference. It also provides reference for the evaluation of the competitiveness of other high-tech Zones in China, and it provides decision-making reference for improving the competitiveness of high-tech Zones.

\section{Acknowledgement}

This research was financially supported by the Hubei Medical College Graduate Startup Gold (Project Number: 2016QDJRW06) and Teaching and Research Project (Project Number: 2016023).

\section{References}

[1] Porter M. E, Cluster and the new economics of competition [J], Harvard Business Review, vol.76, pp.77-90, 1998.

[2] Wang Y, Liu X, Cao Z., The Evaluation for Competitiveness of Hi-Tech Zone on Industrial Cluster and Research[J], Science of Science \& Management of S \& T, vol.30, pp.6-14,2009.

[3] Zhu QY, Wu ML, Evaluation of Competitiveness of High-tech Zones Based on Industrial Clusters-Taking Zhangjiang Hi-Tech Park as an Example[J], Science \& Technology Progress and Policy, vol.25,pp.127-129,2018

[4] Han R, Research on Industrial Cluster Development in High-tech Zone[J], Science \&Technology Industry Parks,pp.1,2018.

[5] Xie QH, Maturity Evaluation of Industrial Clusters in Post-development Region based on AhpGrey fuzzy[J], Journal of Northwestern Poly technical University(Social Sciences),vol.36,pp.57-63, 2016. 